Caroline A. Sullivan (Corresponding author; email: caroline.sullivan1@ gmail.com), Teagasc Environment Research Centre, Johnstown Castle, Wexford, Ireland: Applied Ecology Unit, Centre for Environmental Science, NUI Galway, Ireland; and Plant Science, School of Natural Sciences, NUI Galway, Ireland; John A. Finn, Teagasc Environment Research Centre, Johnstown Castle, Wexford, Ireland; Mike J. Gormally Applied Ecology Unit, Centre for Environmental Science, NUI Galway, Ireland; Micheline Sheehy Skeffington, Botany and Plant Science, School of Natural Sciences, NUI Galway, Ireland.

Cite as follows: Sullivan, C.A., Finn, J.A., Gormally, M.J. and Sheehy Skeffington, M. 2013 Field boundary habitats and their contribution to the area of semi-natural habitats on lowland farms in east Galway، western Ireland. Biology and Environment: Proceedings of the Royal Irish Academy 2013.

DOI: $10.3318 / \mathrm{BIOE}$ 2013.13

Received 3 December 2012 Accepted 11 June 2013. Published 12 November 2013.

\title{
FIELD BOUNDARY HABITATS AND THEIR CONTRIBUTION TO THE AREA OF SEMI- NATURAL HABITATS ON LOWLAND FARMS IN EAST GALWAY, WESTERN IRELAND
}

\author{
Caroline A. Sullivan, John A. Finn, Mike J. Gormally and \\ Micheline Sheehy Skeffington
}

\begin{abstract}
Sustainable agriculture and the provision of environmental public goods are key deliverables for European farming and food production. Farmland biodiversity, cultural landscapes, soil functionality and climate stability are among the environmental public goods provided through agriculture. Future Common Agricultural Policy (CAP) direct payments are intended to be more targeted at the provision of these agricultural deliverables. Field boundaries are an example of such deliverables. They are widespread features that have both environmental and aesthetic functions in farmed landscapes. However, research on their variety, density and contribution to semi-natural habitat cover on farms in Ireland is lacking. This study investigates the diversity and density of all field boundary habitat types on 32 lowland farms in east County Galway, western Ireland. A total of $286 \mathrm{~km}$ of field boundaries were surveyed across six study sites. Five types of field boundary habitats were recorded. The density of field boundaries on the farms studied was high and could have positive implications for delivery of environmental public goods and sustainable farming metrics. In more intensively farmed areas, field boundaries were the only remaining semi-natural habitat on some farms highlighting the need to retain, and improve the ecological quality, of these features. The condition of one field boundary type (hedgerows) was also investigated in further detail. While the density of field boundaries was high on many of the surveyed farms, we found that the hedgerows on these farms were not necessarily in good condition for wildlife.
\end{abstract}

\section{INTRODUCTION}

Sustainable agriculture is a key strategy for European farming and food production. The European Commission has convened a High-Level Steering Board of the European Innovation Partnership on 'Agricultural Productivity and Sustainability' to help meet the challenges of food security, sustainable resource management and environment preservation (DG Agriculture 2013). Integrating functional agricultural biodiversity is a central concept in supporting sustainable agriculture (Bianchi et al. 2013). This integration requires an understanding of those biodiversity elements that support ecosystem services and managing those features appropriately. Management practices include informed choices on the integration of non-crop features such as field boundaries in agricultural landscapes (Bianchi et al. 2013). Typical semi-natural field boundaries in farmed landscapes comprise hedgerows, stone walls, earth banks and any associated watercourse such as streams or drains (Marshall and Moonen 2002). Farmland biodiversity features such as field boundaries form part of our 'green credentials' from a food marketing point of view but, in Ireland, there is a lack of data on the types and densities of field boundaries at farmscales. The role of agriculture in maintaining and improving the provision of environmental public goods is also becoming a prominent justification for expenditure on the Common Agricultural Policy (CAP) (Hart et al. 2011). A variety of environmental public goods can be derived from good farm management and include high quality water, air and soils, agricultural landscapes, climate stability (carbon sequestration and greenhouse gas emissions), resilience to flooding and farmland biodiversity (Cooper et al. 2009). Field boundaries contribute considerably to public goods in a farmed landscape relative to the area of land that they occupy (Cooper et al. 2009).

Field boundaries provide biodiversity in otherwise intensive landscapes in Britain and France (Marshall and Moonen 2002) and elsewhere in Europe. Field boundaries are the most common semi-natural habitats on intensively managed farms in the Netherlands (Manhoudt and de Snoo 2003) and in Denmark they make up a high proportion of 
small biotopes contributing to the biodiversity of agricultural landscapes (Agger and Brandt 1988). The contribution of field boundaries to the seminatural habitat area of farms in Ireland has not been quantified although research from two different regions indicates that the average semi-natural habitat area on farms (including field boundaries in one case) is around 15\% (Sheridan et al. 2011; Sullivan et al. 2011). The quality of these features may also have an impact on the benefits they provide. Hedgerow corridors have a functional importance in a landscape but research suggests that hedgerows quality also has an effect on functionality with greater diversity of vegetation and structural complexity being favourable for movement over hedgerows of a more basic composition (Davies and Pullin 2007). Field boundaries are also important features in extensively farmed landscapes. Identification of HNV farmland is a priority for the current Rural Development Plan (RDP) (2007-2013) and is likely to be a priority for RDP 2014-2020. Ireland is required to identify, support and maintain HNV farmland and to monitor any changes in its extent (European Parliament and Council 2006). Length of hedgerows or other semi-natural field boundaries (of defined quality) could be a HNV feature that would aid the identification of important high nature value farmland (Cooper and Beaufoy 2008). Data on field boundary density and quality are more important now than ever as decisions are made on the CAP 2020, particularly in the context of the greening of Pillar 1 and the next Rural Development Plan (RDP 2014-2020).

Research to date has focused on hedgerows in general (Foulkes and Murray 2005; Fuller 2006; Foulkes 2008) or the classification of hedgerow vegetation (Doogue and Kelly, 2006). There have also been investigations into birds and their interactions with field boundaries on farms in the southeast of Ireland (McMahon et al. 2010a, 2010b), but these studies discuss field boundaries in general or focus on one or two field boundary habitats only. Indeed the research on field boundaries throughout Europe often focuses on a single field boundary type (Forman and Baudry 1984; French and Cummins 2001; Herzon and Helenius 2008) and few refer to the full variety of field boundaries in a farmed landscape (Burel et al. 1998; Aavik and Liira 2010).

Here, we focus on field boundaries on lowland grassland farms in a region of east Galway, western Ireland. The first aim of this study was to quantify the variety and density of field boundaries on a farm-scale to provide important baseline data on these features. Secondly, this research also aimed to quantify the area of field boundaries on farms. This would allow us to assess their contribution to the area of semi-natural habitats, an important aspect of sustainable agriculture. Finally, this study assessed hedgerows in more detail (looking at woody plant species composition and structural condition) as a common field boundary on most farms to give a comprehensive view of both the density and quality of one important component of farmland biodiversity on lowland farms.

\section{MATERIALS AND METHODS}

\section{STUDY AREA}

The study took place in County Galway in the west of Ireland. The east of the county was chosen as, unlike the west of the county, most farmland in this region is outside of European or national nature conservation designated sites such as Special Areas of Conservation (SACs), Special Protection Areas (SPAs) and Natural Heritage Areas (NHAs). East Galway is also representative of much of the midlands in terms of farming practices (Lafferty et al. 1999), river and stream densities, road networks (OSI 2005) and soils (Teagasc 2008). District Electoral Divisions (DEDs) were selected as the main geographical units for this study because farming data are readily available at DED scale from the Central Statistics Office (CSO). East County Galway was split into four quadrants and using stratified random sampling 16 DEDs were selected (four in each quadrant). These DEDs were then assigned numbers (1-4). DED 1 in quadrant one was sampled first, then DED 1 in quadrant two and so on until as many DEDs as possible were sampled. The DEDs sampled were Claregalway, Creggs, Cappard, Scregg, Kilmalinogue and Ahascragh (Fig. 1). Ten per cent of the farms in each DED were selected through contact with local farming organisations and surveyed (total $=32$ farms).

\section{FIELD SURVEYS}

On each of the 32 farms sampled, all habitats including linear field boundary habitats were identified according to Fossitt (2000). See Sullivan et al. (2011) for details on non-linear semi-natural habitats. Where a field boundary was composed of more than one linear habitat type, each habitat present was recorded. As the more common field boundary habitat, hedgerows were investigated in more detail. For fields that had a hedgerow forming all or part of the field boundary, two randomly selected 30-m strips were surveyed along the same side of the hedge as follows: the length of the hedgerow was measured. The length was then divided in five such that two $30 \mathrm{~m}$ lengths and three randomly generated lengths would give the hedgerow length total. Using the following formula, a random number was generated in excel, Random 1 = RANDOMBETWEEN (0, (L0-60)). The result of this was then 


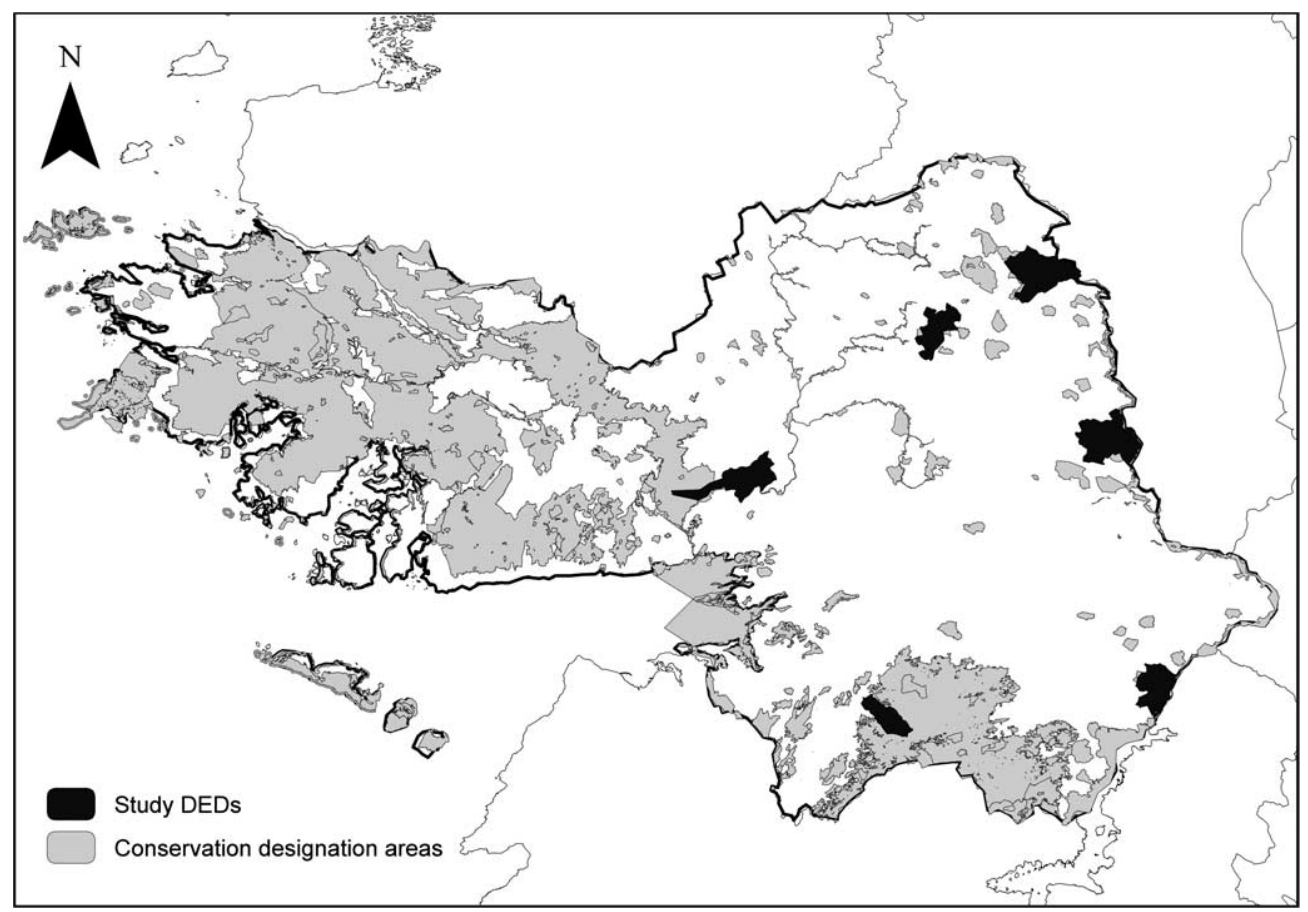

Fig. 1-County Galway showing conservation designation sites (Special Area of Conservation (SAC), Natural Heritage Area (NHA) and Special Protection Area (SPA)) in light grey. Study DEDs are shown in dark grey. Clockwise from the left-most DED is Claregalway, Scregg, Creggs, Ahascragh, Kilmalinogue and Cappard.

included in a formula to generate a second random figure, Random $2=$ RANDBETWEEN ( 0 , ((L-60)-Random 1)). Finally, both these random numbers were used to select the third random number-Random $3=((\mathrm{L}-60)-\mathrm{R}$ andom $1+\mathrm{R}$ andom2)). This gives three random numbers proportional to the hedgerow length that allow randomly selected $30 \mathrm{~m}$ strips to be selected where $\mathrm{L}$ is the total length of hedgerow (Foulkes and Murray 2006). All woody shrub and climber species present in each strip were identified and assigned abundance, based on the DAFOR scale (Kent and Coker 1994). Herbaceous hedgerow plant species were not recorded. Details on hedgerow structure, such as hedgerow function, profile, height, width, gappiness, vigour and adjacent habitat were recorded according to Foulkes and Murray (2006). Tree species present in the hedge were also recorded. Farm management data such as stocking density and farming enterprise were collected from each farmer at the time of field sampling. The hedgerows were assessed as species-rich if four or more native woody shrubs were present (Foulkes and Murray 2006). Whether or not the hedgerow was of favourable condition for wildlife was assessed based on certain structural characteristics adapted from the British Hedgerow Survey handbook (DEFRA 2007) (Table 1). A hedgerow was considered of favourable condition for wildlife if it met all six listed criteria. Field surveys were conducted from May to October of 2006 and 2007.

\section{STATISTICAL ANALYSIS}

The habitat data were digitised using ArcGIS 9.3, facilitating geospatial calculations such as field boundary lengths and non-linear semi-natural habitat areas. Area of field boundaries was calculated by assigning them a width of $1 \mathrm{~m}$. This likely underestimates the true cover of these features on farms (the majority of hedgerows, drainage ditches and earth banks were $>2 \mathrm{~m}$ in width) but still gives an indication of the minimum cover (albeit a very conservative one). Differences in frequencies of species-rich hedgerows and hedgerows of favourable condition among DEDs were examined using the chisquared test. As there was only one degree of freedom, Yates Correction for Continuity was included in each pairwise comparison (Fowler et al. 1998). We also examined whether either hedgerow density or total field boundary density was correlated with the proportion of non-linear semi-natural habitats (\%) on farms (Pearson's correlation coefficient).

Abundance data for the woody plant communities were analysed using PC-Ord version 5 for Windows (McCune and Mefford 2006). Nonmetric Multidimensional Scaling (NMS) analysis was conducted using a Sørenson distance measure, a three-axis solution and 500 real data runs, based on initial autopilot results. NMS was chosen because it avoids the assumption of linear relationships among variables and allows the use of distance measures suited to non-normally distributed data (McCune 
Table 1-Criteria that must be met for a hedgerow to be considered in good or favourable condition for wildlife (adapted from DEFRA 2007). All six criteria must be met for a hedgerow to be considered in 'favourable condition'. The percentage of hedgerows that did not fulfil each individual criterion is included.

Threshold for favourable condition for wildlife

Hedgerows surveyed that did not fulfil this condition $(\%)$

Average height at least $2 \mathrm{~m}$

Average width at least $1.5 \mathrm{~m}$

Less than $10 \%$ gaps, with no individual gap wider than $5 \mathrm{~m}$

0

0

Base of woody component closer than $50 \mathrm{~cm}$ to the ground

Less than $10 \%$ introduced non-native species

At least $2 \mathrm{~m}$ of undisturbed (uncultivated) ground from hedge

Hedgerows in this study that were not in favourable condition for wildlife (\%) hedgerows, drainage ditches, stone walls, treelines and earth banks (see Fig. 2). The field boundaries totalled $286 \mathrm{~km}$ in length and the mean number $( \pm$ SE) of field boundary habitat types per farm was 4.0 $( \pm 1.0)$. The majority $(93 \%)$ of the farms had three or more field boundary habitats. Hedgerows were the most common field boundary overall (44\%) (Fig. 3a) though they were not necessarily the dominant field boundary in every DED (see Claregalway farms, Fig. 4). Drainage ditches were also common; they occurred frequently as single boundaries (18\%) and as components of double boundaries (Fig. 3a and b). Stone walls comprised $>10 \%$ of the single field boundaries but were not a major component of double boundaries (Fig. 3a and $\mathrm{b}$ ). Of the field boundaries surveyed, 16 different combinations of the five linear habitats

Five types of linear field boundaries (excluding wire fencing) were identified on the 32 farms,
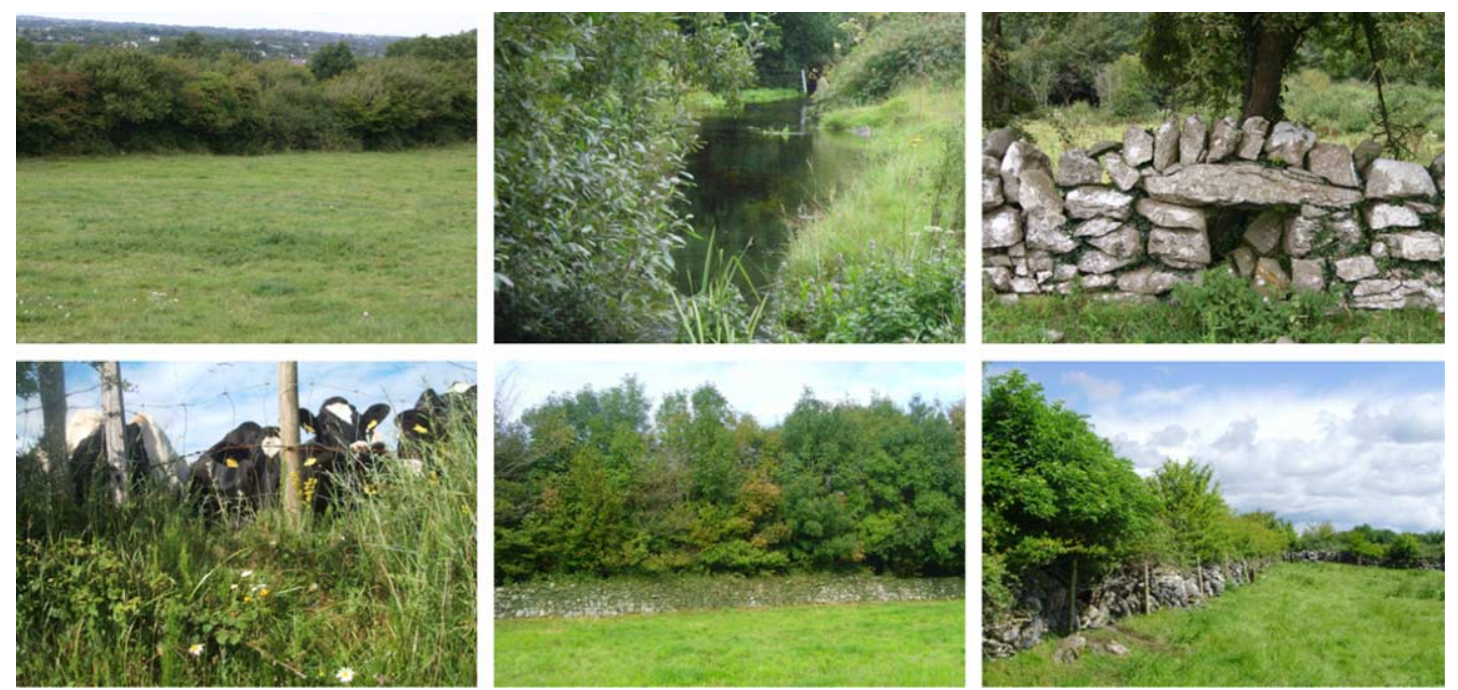

Fig. 2-Field boundary habitats on farms in east County Galway. Top L-R good quality hedgerow with Crataegus monogyna and Corylus avellana; drainage ditch with aquatic vegetation adjacent to a grassy field margin; dry stone wall with closed-off sheep run. Bottom L-R earth bank (and wire fence) with Galium verum, Centuarea nigra and Leucanthemum vulgare; treeline with dry stone wall; a Sambucus nigra and Crataegus monogyna hedgerow with dry stone wall and wire fencing. 

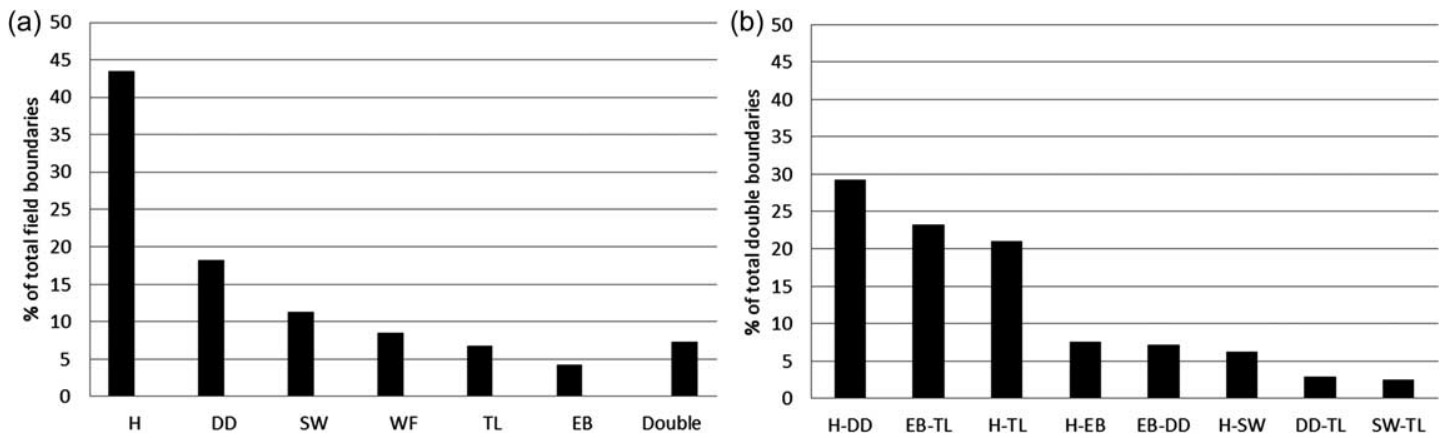

Fig. 3-(a) Field boundary components on farms in east County Galway. The value for triple boundaries(i.e. boundaries comprising 3 field boundary types) was low $(<1 \%)$ and is not displayed. (b) Composition of double boundary component. Key to boundary types: $\mathrm{H}=$ Hedgerow, $\mathrm{DD}=$ Drainage Ditch, $\mathrm{SW}=\mathrm{Stone}$ Wall, $\mathrm{TL}=\mathrm{Treeline}$ and $\mathrm{EB}=$ Earth Bank, WF = Wire Fencing.

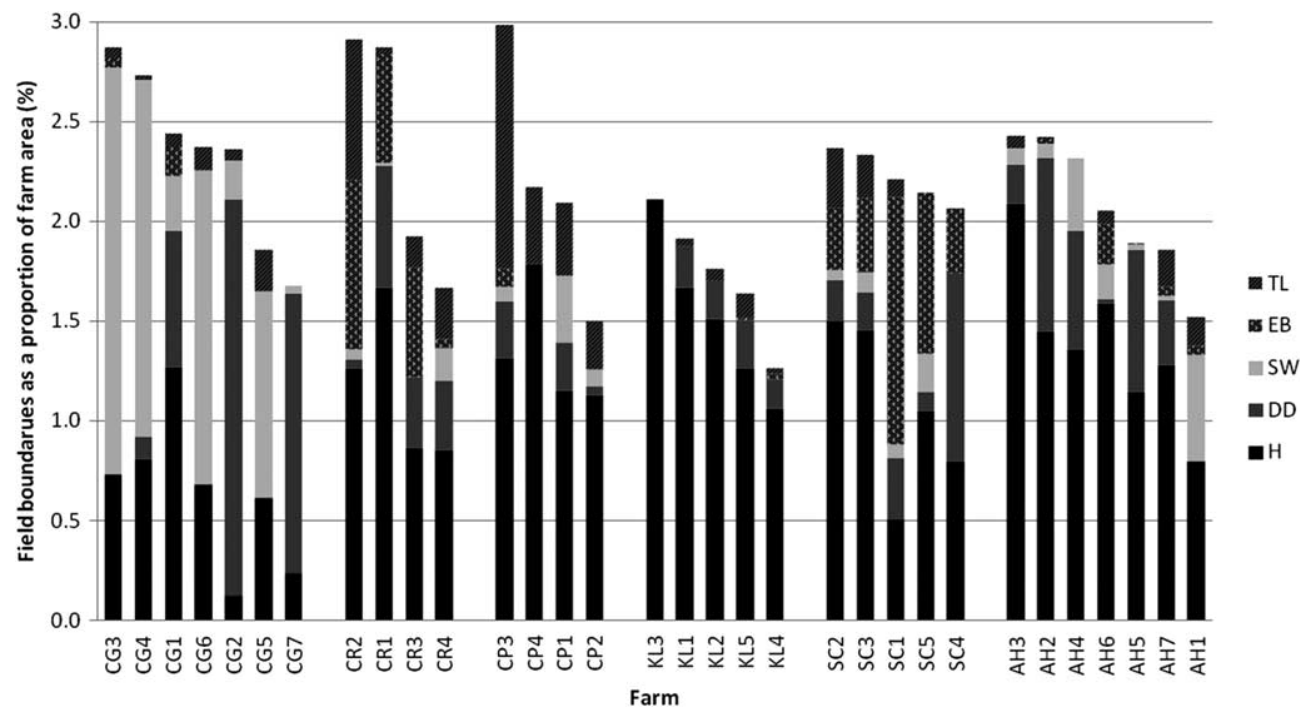

Fig. 4-Field boundary habitat as a percent of total farm area, with relative contribution of each of the five main habitat types. Data are arranged by DED, from highest to lowest area of boundary habitat on sampled farms. DED codes: CG = Claregalway, $\mathrm{CR}=$ Creggs, $\mathrm{CP}=$ Cappard, $\mathrm{KL}=$ Kilmalinogue, $\mathrm{SC}=$ Scregg and $\mathrm{AH}=\mathrm{Ahascragh}$.

were observed. The majority were made up of one field boundary but just over $7 \%$ of the field boundaries were composed of two field boundary habitats and these are referred to here as double boundaries (Fig. 3a). The composition of the double boundaries varied (Fig. 3b). Hedgerows with drainage ditches were the most common double boundaries $(29.2 \%)$, followed by earth banks with treelines $(23.2 \%)$ and hedgerows with treelines (21.1\%). The remaining combinations each made up $<10 \%$ of the double boundaries. Triple boundaries (i.e. boundaries that comprised three linear semi-natural habitats) made up $<1 \%$ of the boundaries surveyed. Wire fences are not the most important components of the stock-proof barriers in these regions, with $11 \%, 10 \%, 10 \%, 10 \%, 7 \%$ and $3 \%$ of field boundary lengths for Ahascragh, Claregalway Scregg, Kilmalinogue, Cappard and
Creggs, respectively, recorded as wire fences. Field boundary density was $>200 \mathrm{~m} \mathrm{ha}^{-1}$ for the majority $(63 \%)$ of the farms surveyed; the average density $( \pm$ SE) was $219 \mathrm{~m}( \pm 12 \mathrm{~m})$ per ha for all farms surveyed. Field boundary densities were highest in Scregg DED (all $>200 \mathrm{~m} \mathrm{ha}^{-1}$ ) and only on farms in Kilmalinogue DED were the majority less than $200 \mathrm{~m} \mathrm{ha}^{-1}$ (Table 2).

Hedgerows were the only field boundary habitat to occur on all 32 farms (Fig. 4) but other field boundaries were notable components in some DEDs, e.g. stone walls in Claregalway DED, treelines in Cappard DED and earth banks in Scregg DED (Fig. 4). Field boundaries can contribute a considerable proportion of the semi-natural habitat area on farms. Considered independently of non-linear semi-natural features, field boundaries accounted for an average of $2.1 \%$ 
Table 2-Field boundary density per farm in descending order of density arranged by DED. The hedgerow density $\left(\mathrm{m} \mathrm{ha}^{-1}\right)$ and percentage of total boundary that were hedgerows are also given, as well as the percent contribution of field boundaries to the total area of semi-natural habitat on each farm. DED codes: CG=Claregalway, $C R=$ Creggs, $\mathrm{CP}=$ Cappard, $\mathrm{KL}=$ Kilmalinogue, $\mathrm{SC}=$ Scregg and $\mathrm{AH}=$ Ahascragh.

\begin{tabular}{|c|c|c|c|c|}
\hline$D E D$ & $\begin{array}{c}\text { All boundary } \\
\text { density }\left(m h a^{-1}\right)\end{array}$ & $\begin{array}{l}\text { Hedgerow density } \\
\quad\left(m h a^{-1}\right)\end{array}$ & $\begin{array}{c}\text { Proportion of field } \\
\text { boundaries that were } \\
\text { hedgerow (\%) }\end{array}$ & $\begin{array}{c}\text { Field boundaries as a\% of } \\
\text { semi-natural habitats }\end{array}$ \\
\hline CG3 & 287.0 & 72.3 & 25 & 81 \\
\hline CG4 & 273.2 & 80.4 & 29 & 25 \\
\hline CG1 & 243.9 & 126.5 & 52 & 100 \\
\hline CG6 & 237.3 & 67.5 & 28 & 100 \\
\hline CG2 & 235.8 & 23.7 & 5 & 81 \\
\hline CG5 & 185.5 & 60.7 & 33 & 17 \\
\hline CG7 & 167.4 & 23.4 & 14 & 3 \\
\hline CR2 & 291.1 & 126.3 & 43 & 39 \\
\hline CR1 & 286.8 & 166.4 & 58 & 27 \\
\hline CR3 & 192.2 & 42.7 & 45 & 7 \\
\hline CR4 & 166.5 & 85.2 & 51 & 8 \\
\hline CP3 & 298.3 & 130.8 & 44 & 15 \\
\hline $\mathrm{CP} 4$ & 216.9 & 178.2 & 82 & 9 \\
\hline $\mathrm{CP} 1$ & 209.3 & 114.6 & 55 & 6 \\
\hline CP2 & 149.8 & 112.6 & 75 & 8 \\
\hline KL3 & 210.6 & 210.6 & 100 & 59 \\
\hline KL1 & 188.8 & 164.5 & 87 & 51 \\
\hline KL2 & 172.6 & 146.9 & 85 & 100 \\
\hline KL5 & 163.8 & 126.2 & 77 & 41 \\
\hline KL4 & 126.0 & 105.9 & 84 & 17 \\
\hline SC2 & 236.2 & 149.7 & 63 & 34 \\
\hline SC3 & 233.1 & 145.1 & 62 & 5 \\
\hline SC1 & 220.8 & 50.2 & 23 & 34 \\
\hline SC5 & 214.1 & 104.9 & 49 & 4 \\
\hline SC4 & 206.3 & 79.1 & 38 & 40 \\
\hline AH3 & 243.1 & 208.3 & 86 & 9 \\
\hline AH2 & 242.4 & 144.4 & 60 & 14 \\
\hline AH4 & 231.6 & 135.7 & 59 & 19 \\
\hline AH6 & 205.1 & 158.3 & 77 & 13 \\
\hline AH5 & 188.9 & 114 & 60 & 4 \\
\hline AH7 & 185.2 & 127.5 & 69 & 40 \\
\hline AH1 & 152.0 & 79.3 & 52 & 14 \\
\hline
\end{tabular}

$( \pm 0.4)$ of the total farm area. The maximum farm area covered by the field boundaries was $2.9 \%$ (CP3, Fig. 4) and the minimum was 1.3\% (KL4, Fig. 4). Since the field boundary area is based on a $1 \mathrm{~m}$ width for all boundaries it is likely that this is an underestimation and that these figures would double in many cases (the majority of hedgerows were $>2 \mathrm{~m}$ in width). On some farms (CG1, CG6 and KL2), the field boundaries were the only seminatural habitats recorded on the farm (Table 2). However, there was considerable variation within DEDs and on farms CG7, SC5 and AH5, the field boundaries comprised just $3-4 \%$ of the total area of semi-natural habitat recorded on these farms (Table 2). The possibility of using hedgerow density or total field boundary density as a proxy 
Table 3-Frequency of woody plant species in farm hedgerows in east Galway arranged in order of decreasing frequency. Species in dark grey are woody climbers and species in light grey are trees. Tree species are also listed as shrubs where they were $<4 \mathrm{~m}$ tall and formed part of the hedgerow due to management.

\begin{tabular}{|c|c|}
\hline Woody plant species & Frequency (\%) \\
\hline Crataegus monogyna & 95.6 \\
\hline Rubus fruticosus & 90.8 \\
\hline Fraxinus excelsior & 53.8 \\
\hline Prunus spinosa & 45.8 \\
\hline Hedera helix & 45.8 \\
\hline Rosa canina & 44.2 \\
\hline Sambucus nigra & 32.3 \\
\hline Ilex aquifolium & 29.1 \\
\hline Ligustrum vulgare* & 25.5 \\
\hline Ulex europaeus & 24.7 \\
\hline Salix sp. & 20.7 \\
\hline Fraxinus excelsior & 13.9 \\
\hline Lonicera periclymenum & 13.5 \\
\hline Corylus avellana & 13.1 \\
\hline Salix sp. & 10.4 \\
\hline Euonymus europaeus & 7.6 \\
\hline Acer pseudoplatanus* & 7.2 \\
\hline Fagus sylvatica* & 6.8 \\
\hline Symphoricarpos albus* & 3.6 \\
\hline Aesculus hippocastanum* & 3.6 \\
\hline Ulmus sp. & 3.2 \\
\hline Quercus sp. & 3.2 \\
\hline Alnus glutinosa & 2.4 \\
\hline Malus domestica* & 2.0 \\
\hline Alnus glutinosa & 1.6 \\
\hline Fagus sylvatica* & 1.6 \\
\hline Pinus sp. * & 1.6 \\
\hline Corylus avellana & 1.6 \\
\hline Lonicera nitida ${ }^{\star}$ & 1.2 \\
\hline Viburnum opulus & 1.2 \\
\hline Betula pubescens & 1.2 \\
\hline Ilex aquifolium & 1.2 \\
\hline Sambucus nigra & 1.2 \\
\hline Betula pubescens & 0.8 \\
\hline Prunus avium & 0.8 \\
\hline Prunus domestica* & 0.8 \\
\hline Quercus sp. & 0.8 \\
\hline Fuchsia magellanica* & 0.8 \\
\hline Populus sp. & 0.8 \\
\hline Malus sylvestris & 0.4 \\
\hline
\end{tabular}

Note: Asterisk $\left({ }^{\star}\right)$ symbol denotes non-native status after Reynolds (2002). for semi-natural habitat cover on a farm was also investigated. However, there was no significant correlation between either farm hedgerow density $\left(r^{2}=-0.232, P=0.201\right)$, or total field boundary density $\left(r^{2}=-0.137, P=0.454\right)$ and the seminatural habitat area of that farm.

\subsection{HEDGEROW CONDITION}

A total of $138 \mathrm{~km}$ or $48 \%$ of the field boundaries studied were hedgerows or had a hedgerow component. A total length of $46.9 \mathrm{~km}$ of hedgerow was surveyed on 32 farms ( $n=251$ hedgerows). Thirty-one woody plant species were recorded in the surveyed hedgerows; the majority of these were woody shrubs, with some woody climbers and trees (Table 3). Of the 31 species, ten were non-native. The mean number $( \pm$ SE) of woody shrubs in the hedgerows was 2.9 ( \pm 0.8). The maximum number of woody shrubs in any one hedgerow was seven. Just under one-third (31.5\%) of the hedgerows surveyed were species-rich (contained four or more native woody plants) (Table 4). A chisquared test showed statistically significant differences in the frequencies of species-rich hedgerows among DEDs (see Appendix A). The frequency of species-rich hedgerows in Kilmalinogue (82.4\%) was significantly higher than in any other DED surveyed. The frequency of species-rich hedgerows in Claregalway $(8.7 \%)$ was significantly lower than in Cappard, Kilmalinogue and Scregg.

A total of $44 \%$ of the surveyed hedgerows were in favourable condition (Table 1). All hedgerows were $>1.5 \mathrm{~m}$ wide and satisfied 'width' criteria for favourable condition. More than $80 \%$ of the hedgerows surveyed were at least $2 \mathrm{~m}$ wide. A chi-squared test showed statistically significant

Table 4-Frequencies of surveyed hedgerows that were species-rich and in 'favourable condition' per DED. Far right column shows the mean percent of semi-natural habitats accounted for by field boundaries on surveyed farms per DED.

\begin{tabular}{lcc}
\hline DED & $\begin{array}{c}\text { Frequency of } \\
\text { species-rich hedge- } \\
\text { rows (\%) }\end{array}$ & $\begin{array}{c}\text { Hedgerows in } \\
\text { 'favourable } \\
\text { condition' (\%) }\end{array}$ \\
\hline Claregalway & 8.7 & 23.9 \\
Creggs & 22.9 & 35.4 \\
Cappard & 34.9 & 51.2 \\
Kilmalinogue & 82.4 & 58.8 \\
Scregg & 32.1 & 46.4 \\
Ahascragh & 23.1 & 53.8 \\
Total & 31.5 & 44.2 \\
\hline
\end{tabular}




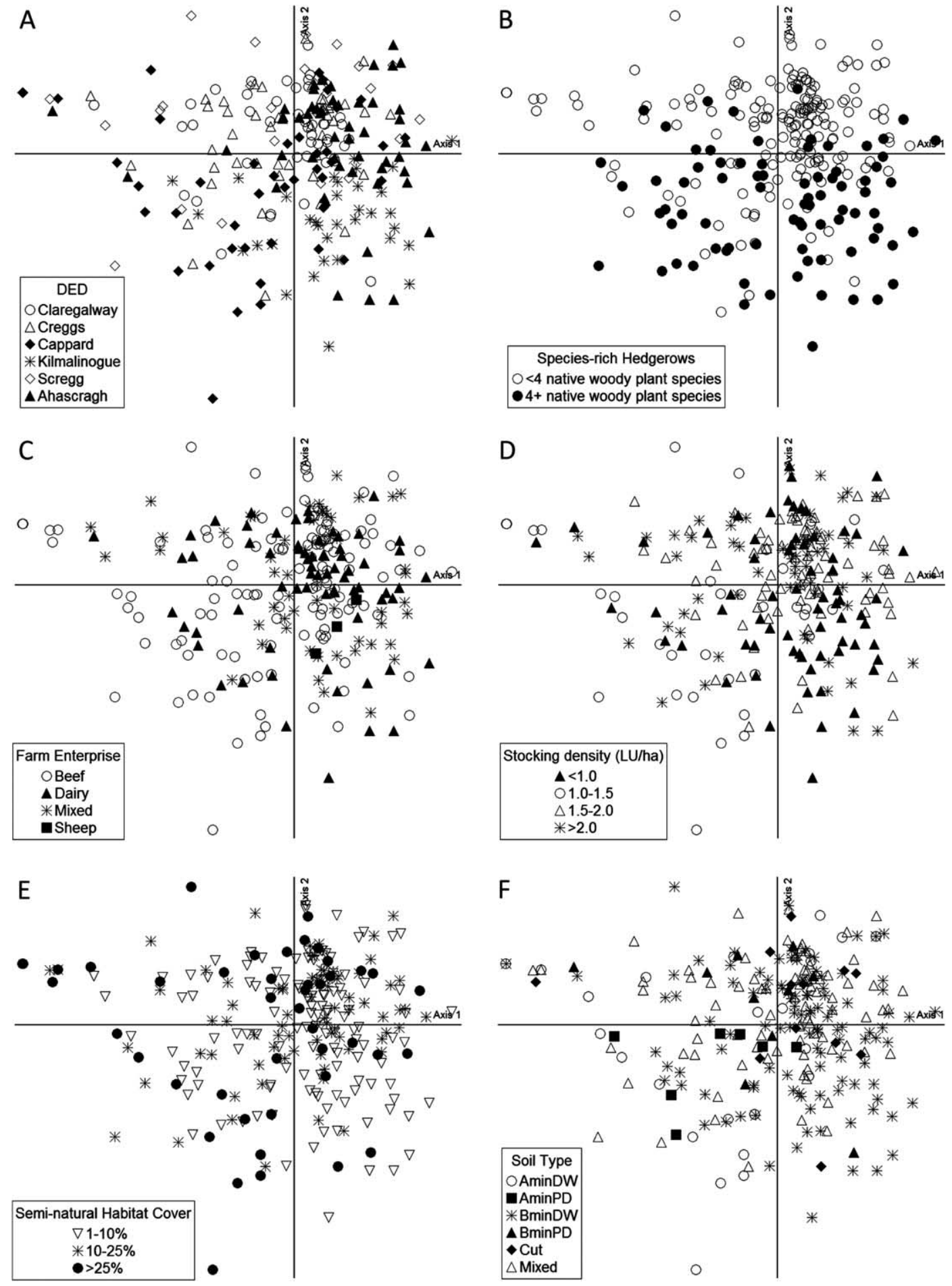

Fig. 5-NMS ordination of woody plant species in hedgerows showing axes 1 and 2, with overlays of (a) DED, (b) speciesrich hedgerows, (c) farm enterprise, (d) stocking density, (e) non-linear semi-natural habitat cover and (f) dominant soil type. AminDW $=$ Deep, well drained mineral soil derived from mainly acidic parent materials, AminPD $=$ Deep, poorly drained mineral soil derived from mainly acidic parent materials, BminDW $=$ Deep well drained mineral soil derived from mainly alkaline parent materials, BminPD = poorly drained mineral soil derived from mainly alkaline parent materials, Cut $=$ Cutaway Blanket bog.

differences in the frequencies of hedgerows in favourable condition among DEDs (see Appendix B). The frequency of hedgerows in 'favourable condition' in Claregalway (23.9\%) was significantly lower than that in Cappard, Kilmalinogue and Ahascragh. There was no statistically significant 
difference in species-richness of hedgerows among the other DEDs surveyed. These chi-squared test results show differences in the frequency of both species-richness and favourable structural characteristics of hedgerows among the DEDs surveyed. The majority of hedgerows (56\%) were not in favourable condition. The most common reasons were gappiness (38\%), the base being too open and scrawny $(35 \%)$ or the presence of more than $10 \%$ non-native species $(10 \%)$ or a combination of these (Table 1).

The NMS analyses, based on hedgerow woody species composition, indicated that axes 1 and 2 accounted for most of the variance in the distance matrix, explaining $44 \%$ and $22 \%$, respectively (Fig. 5). Axis 3 accounted for $17 \%$ of the variance. For clarity, species names are not shown, but Crataegus monogyna occurred throughout the majority of hedgerows (96\%); Corylus avellana and Euonymus europaeus were more frequent in hedgerows in the lower quadrants of the NMS and Ulex europaeus most frequently occurred in hedgerows in the top left quadrant. Woody species composition of hedgerows did not vary much among DEDs. Kilmalinogue hedges are concentrated in the lower right quadrant of the ordination and Cappard hedges are mostly in the bottom left (Fig. 5a). These lower quadrants are where the species-rich hedgerows are concentrated (Fig. 5b), indicating that Cappard and Kilmalinogue have more speciesrich hedgerows than the other DEDs. This in turn corresponds with the occurrence of $C$. avellana and E. europaeus known to be more abundant in speciesrich hedgerows (Pollard et al. 1974; Foulkes and Murray 2005). Woody species composition did not vary according to farm enterprise (Fig. 5c) or stocking density (Fig. 5d) although hedges on farms with stocking densities of $<1 \mathrm{LU}$ ha $^{-1}$ occurred more on the right-hand side of the ordination (black triangles). It is notable that farms with a high proportion of other (i.e. non-linear) semi-natural habitat were not necessarily those with species-rich hedgerows (compare Fig. 5b and e). In fact, many of the more species-rich hedgerows (in the bottom right quadrant) occur on farms with $<10 \%$ nonlinear semi-natural habitat area (Fig. 5e). These hedgerows also mostly occurred over the alkaline, well-drained soils of Kilmalinogue and Ahascragh (as opposed to more acid or waterlogged soils) (Fig. 5a and f).

\section{DISCUSSION}

Hedgerows, stone walls, earth banks, drainage ditches and treelines each contribute differently to biodiversity, due to the variety in their structure and the habitats they provide for plants and animals (Forman and Baudry 1984; Smart et al. 2002;
Herzon and Helenius 2008; Aavik and Liira 2010). In this study, on average, there were four field boundary types per farm. Current agri-environment schemes tend to focus on one or two of the field boundaries that occur on farms, incorporating them into the farm management plan and advising on their management. In Britain and Ireland, the protection and management of hedgerows and stone walls are addressed by agri-environment schemes (DAFF 2006; NE 2008), as are drainage ditches in the Netherlands (Blomqvist et al. 2009). In most cases, management recommendations are lacking for the full variety of field boundary habitats that occur on farms, including double boundaries. The results presented here highlight the need to consider all field boundary types and compositions (not just hedgerows and stone walls) when assessing the biodiversity that is contributing to sustainable agriculture. Drainage ditches in particular were important components in the studied farms that are largely overlooked in Ireland. The integration of functional agricultural biodiversity in agroecosystems requires understanding of these biodiversity elements and translation of such knowledge into tailored farm and landscape management practices (Bianchi et al. 2013).

In Brittany, hedgerow densities of $273 \mathrm{~m} \mathrm{~h}^{-1} \mathrm{a}$ was considered to be high (bocage landscape) and $113 \mathrm{~m} \mathrm{ha}^{-1}$ was considered to be low (open landscape) (Baudry et al. 2000). The average density of the field boundary habitats, predominantly hedgerows, on the surveyed farms in this study was high $\left(>200 \mathrm{~m} \mathrm{ha}^{-1}\right.$ for the majority of farms). Per unit area, field boundaries make a considerable contribution to environmental public goods, so a higher density of boundaries and margins will often be associated with a higher than average provision of environmental benefits (Cooper et al. 2009). Field boundary metrics such as these could be important for initiatives such as Origin Green (BordBia 2012) in which food companies commit to the development of farm-scale sustainability through maintaining and/or improving sustainability in key target areas such as greenhouse gas emissions, water, energy and biodiversity. Similar metrics are in place in the UK. Farmers can follow a 'conservation grade' sustainability protocol in return for a contracted premium price for their crop. They commit to dedicating a minimum of $10 \%$ of their farm area to wildlife habitats. Up to $2 \%$ of these can be field boundaries (Conservation Grade Producers 2011). On arable farms in the Netherlands the total area of semi-natural habitats recorded was just $2.1 \%$, a high proportion of which was field boundaries (Manhoudt and de Snoo 2003). In this study, field boundaries alone represented an average of $2.1 \%$ of the farm area surveyed. This figure is conservative and they may, in fact, make up twice that. Data such as these may validate Ireland's 
'green credentials' from a food marketing point of view.

Field boundaries represented between 3\% and $100 \%$ of the semi-natural habitats identified on the farms surveyed. Where field boundaries provide the only semi-natural habitat on a farm they should be actively targeted through agri-environment schemes to ensure that these existing habitats are, firstly, retained and, secondly, managed in the most appropriate manner to promote connectivity with farms or landscapes with greater densities of seminatural habitats and to ensure sustainable resource management and environment preservation. A high density of field boundaries is also a HNV farmland feature (Cooper and Beaufoy 2008), though their presence alone does not indicate HNV farmland. This research indicated that hedgerow density or total field boundary density were not suitable as proxies for semi-natural habitat cover on a farm but they may still be important HNV features where the semi-natural habitat area is high. Where the field boundaries occur within less intensively managed land, they will normally be of higher conservation value because they usually have more complex interrelations of species and habitats (Beier and Noss 1998; Burel and Baudry 2005; Cooper and Beaufoy 2008).

While the presence of these features is important, the quality of these field boundary networks also needs to be measured. The ecological processes and species associated with agricultural habitats are greatly affected by a number of factors such as the spatial scale of the fields and farming system and the presence and ecological quality of field boundary habitats and landscape diversity (Poláková et al. 2011). The more intensively farmed DEDs had some of the lowest areas of semi-natural habitats, but had the highest frequency of speciesrich hedgerows (Kilmalinogue DED, Table 4). The occurrence of more species-rich hedgerows in these areas is probably related to soil quality. Areas with good soil quality (base-rich and well-drained) are often converted to more intensive agriculture and so semi-natural habitat area is low; however, the hedgerows have probably been retained due to their stock-proofing or boundary-marking properties. McMahon et al. (2010a) made similar observations on farms in south-east Ireland. Good quality hedgerows in intensively farmed areas can provide essential networks for species connectivity with more extensively farmed and natural areas in the same landscape (Grashof-Bokdam and Langevelde 2005; Schippers et al. 2009). That said, almost $40 \%$ of the hedgerows in Kilmalinogue DED were not in favourable condition for wildlife. In fact $68.5 \%$ of the hedgerows in this study were not species-rich and $44.2 \%$ of them were not in favourable condition for wildlife. This suggests that while the field boundary density in a region might be high, they are not necessarily of good quality. The most common reasons for these hedgerows not being in favourable condition were gappiness, open and scrawny bases and the presence of more than $10 \%$ non-native species. According to DEFRA (2007), enhancement of the diversity of plant species and structure of a hedgerow to promote wildlife diversity may be achieved if a hedgerow is in favourable condition. Simple measures such as increasing the hedgerow width (Aavik and Liira 2010) or targetting non-native plant species in the hedgerows through agrienvironment or rural development schemes could enhance the biodiversity of these features further. It could also be achieved through community-based schemes that promote field boundaries and their role in the natural heritage of an area such as the Golden Mile competition in County Galway for hedgerows (GalwayCoCo 2012). Although, given the variety of field boundaries on Irish farms these initiatives should be extended beyond hedgerows. Further research is necessary to investigate methods of assessing the quality of the other field boundary types common on Irish farms, particularly drainage ditches. Information on the diversity and quality of field boundaries is important for plant, habitat and landscape diversity perspectives but they are also becoming increasingly important from consumer perspectives as measures of sustainable farming practices.

\section{ACKNOWLEDGEMENTS}

We sincerely thank all the landowners who gave permission for us to survey their farms. Thanks to Janice Fuller, Heather Lally, Julien Meyroneinc and Barry Kearns for assistance with hedgerow surveying and data entry. Thanks also to David Bourke and Daire Ó hUallacháin for reviewing drafts of the paper and to two anonymous reviewers for their useful comments and suggestions. This work was funded by Teagasc (The Irish Agriculture and Food Development Authority) under the Walsh Fellowship Scheme.

\section{REFERENCES}

Aavik, T. and Liira, J. 2010 Quantifying the effect of organic farming, field boundary type and landscape structure on the vegetation of field boundaries. Agriculture, Ecosystems and Environment 135, 178-86.

Agger, P. and Brandt, J. 1988 Dynamics of small biotopes in Danish agricultural landscapes. Landscape Ecology 1, 227-40.

Baudry, J., Burel, F., Thenail, C. and Le Coeur, D. 2000 A holistic landscape ecological study of the interactions between farming activities and ecological 
FIELD BOUNDARIES' CONTRIBUTION TO SEMI-NATURAL HABITATS ON LOWLAND FARMS

patterns in Brittany, France. Landscape and Urban Planning 50, 119-28.

Beier, P. and Noss, R.F. 1998 Do habitat corridors provide connectivity? Conservation Biology 12, 1241-52.

Bianchi, F.J.J.A., Mikos, V., Brussaard, L., Delbaere, B. and Pulleman, M.M. $2013 \quad$ Opportunities and limitations for functional agrobiodiversity in the European context. Environmental Science and Policy 27, 223-31.

Blomqvist, M.M., Tamis, W.L.M. and de Snoo, G.R. 2009 No improvement of plant biodiversity in ditch banks after a decade of agri-environment schemes. Basic and Applied Ecology 10, 368-78.

BordBia 2012 What is origin green? Bord Bia (Irish Food Board). http://www.bordbia.ie/origingreen/ whatisorigingreen/pages/default.aspx (accessed 12 September 2012).

Burel, F. and Baudry, J. 2005 Habitat quality and connectivity in agricultural landscapes: the role of land use systems at various scales in time. Ecological Indicators 5, 305-13.

Burel, F., Baudry, J., Butet, A., Clergeau, P., Delettre, Y., Le Coeur, D., Dubs, F., Morvan, N., Paillat, G., Petit, S., Thenail, C., Brunel, E. and Lefeuvre, J.-C. 1998 Comparative biodiversity along a gradient of agricultural landscapes. Acta Oecologica 19, 47-60.

Conservation Grade Producers 2011 Conservation Grade Farming Protocol. St. Neots, Cambridgeshire. Conservation Grade Producers Ltd.

Cooper, T. and Beaufoy, G. 2008 A guidance document: the application of the high nature value impact indicator. Brussels. Institute for European Environmental Policy.

Cooper, T., Hart, K. and Baldock, D. 2009 The provision of public goods through agriculture in the European Union. London. Institute for European and Environmental Policy.

DAFF 2006 The Rural Environment Protection Scheme (REPS). Specification for REPS planners in the preparation of REPS 4 plans. Dublin. Department of Agriculture, Food and Fisheries.

Davies, Z. and Pullin, A. 2007 Are hedgerows effective corridors between fragments of woodland habitat? An evidence-based approach. Landscape Ecology 22, 333-51.

DEFRA 2007 Hedgerow Survey Handbook: A standard procedure for local surveys in the UK. London. Department for Environment, Food and Rural Affairs.

DG Agriculture 2013 Agriculture and rural development. Available at http://ec.europa.eu/agriculture/ eip/events/steering-board-01_en.htm (accessed on 26 February 2013).

Doogue, D. and Kelly, D.L. 2006 Woody plant assemblages in the hedges of eastern Ireland: products of history or of ecology. Biology and Environment 106B (3), 237-50.

European Parliament and Council 2006 2006/144/ EC: Council Decision of 20 February 2006 on Community strategic guidelines for rural development (programming period 2007 to 2013). Official Journal of the European Union L 55, 20-29.
Forman, R.T.T. and Baudry, J. 1984 Hedgerows and hedgerow networks in landscape ecology. Environmental Management 8, 495-510.

Fossitt, J. 2000 A guide to habitats in Ireland. Kilkenny. The Heritage Council.

Foulkes, N. 2008 County Sligo hedgerow survey report. Sligo. Sligo County Council and the Heritage Council.

Foulkes, N. and Murray, A. 2005 County Laois Hedgerow survey report. Portlaoise. Laois County Council.

Foulkes, N. and Murray, A. 2006 A methodology for the recording of hedgerow extent, species composition, structure and condition in Ireland. Tearmann 5, 75-89.

Fowler, J., Cohen, L. and Jarvis, P. 1998 Practical statistics for field biology. Chichester and New York. Wiley.

French, D.D. and Cummins, R.P. $2001 \quad$ Classification, composition, richness and diversity of British hedgerows. Applied Vegetation Science 4, 213-28.

Fuller, J. 2006 East Galway hedgerow survey. Galway. Galway County Council.

GalwayCoCo 2012 The 'Golden Mile' of Galway. Galway. Galway County Council. Available at http://www.galway.ie/en/Services/Heritage/Golden Mile/golden\%20mile\%20advertisment $\% 20$ Mar\%20 2012\%20(2).pdf (accessed on 20 March 2013).

Grashof-Bokdam, C.J. and Langevelde, F. 2005 Green veining: Landscape determinants of biodiversity in European agricultural landscapes. Landscape Ecology 20, 417-439.

Hart, K., Baldock, D., Weingarten, P., Osterburg, B., Povellato, A., Vanni, F., Pirzio-Biroli, C. and Boyes, A. 2011 What tools for the European agricultural policy to encourage the provision of public goods? Brussels. European Parliament.

Herzon, I. and Helenius, J. 2008 Agricultural drainage ditches, their biological importance and functioning. Biological Conservation 141, 1171-83.

Kent, M. and Coker, P. 1994 Vegetation description and analysis: a practical approach. Chichester. John Wiley.

Lafferty, S., Commins, P. and Walsh, J.A. 1999 Irish agriculture in transition: a census atlas of agriculture in the Republic of Ireland. Maynooth, Co. Kildare, Dublin. Teagasc in Association with Department of Geography, National University of Ireland.

Manhoudt, A.G.E., de Snoo, G.R. 2003 A quantitative survey of semi-natural habitats on Dutch arable farms. Agriculture, Ecosystems \& Environment 97, 235-40.

Marshall, E.J.P. and Moonen, A.C. 2002 Field margins in northern Europe: their functions and interactions with agriculture. Agriculture, Ecosystems E Environment 89, 5-21.

McCune, B. and Grace, J.B. 2002 Analysis of ecological communities. Gleneden Beach, Oregon. MjM Software Design.

McCune, B. and Mefford, M.J. 2006 PC-ORD. Multivariate analysis of ecological data, Version 5.1. Gleneden Beach, Oregon. MjM Software.

McMahon, B.J., Helden, A., Anderson, A., Sheridan, H., Kinsella, A. and Purvis, G. 2010a Interactions between livestock systems and biodiversity in 


\section{BIOLOGY AND ENVIRONMENT}

South-East Ireland. Agriculture, Ecosystems \& Environment 139, 232-38.

McMahon, B.J., Sheridan, H., Kinsella, A. and Purvis, G. 2010b An assessment of bird species within Irish agricultural landscapes using the Field Boundary Evaluation and Grading System. Bird Study 57, 108-15.

NE 2008 Entry level stewardship handbook 2nd edn. Sheffield. Natural England.

OSI 2005 1:50,000 maps, Discovery Series. Dublin. Ordnance Survey Ireland.

Poláková, J., Tucker, G., Hart, K., Dwyer, J. and Rayment, M. 2011 Addressing biodiversity and habitat preservation through measures applied under the Common Agricultural Policy. Report Prepared for DG Agriculture and Rural Development, Contract No. 30-CE-0388497/00-44. Institute for European Environmental Policy, London.

Pollard, E., Hooper, M.D., Moore, N.W. 1974 Hedges. London. Collins.

Reynolds, S.C.P. 2002 A catalogue of alien plants in Ireland. Glasnevin, Ireland. National Botanic Gardens.
Schippers, P., Grashof-Bokdam, C., Verboom, J., Baveco, J., Jochem, R., Meeuwsen, H. and Van Adrichem, M. 2009 Sacrificing patches for linear habitat elements enhances metapopulation performance of woodland birds in fragmented landscapes. Landscape Ecology 24, 1123-1133.

Sheridan, H., McMahon, B.J., Carnus, T., Finn, J.A., Anderson, A., Helden, A.J., Kinsella, A. and Purvis, G. 2011 Pastoral farmland habitat diversity in south-east Ireland. Agriculture, Ecosystems \& Environment 144, 130-5.

Smart, S.M., Bunce, R.G.H., Firbank, L.G. and Coward, P. 2002 Do field boundaries act as refugia for grassland plant species diversity in intensively managed agricultural landscapes in Britain? Agriculture, Ecosystems \& Environment 91, 73-87.

Sullivan, C.A., Bourke, D., Skeffington, M.S., Finn, J.A., Green, S., Kelly, S. and Gormally, M.J. 2011 Modelling semi-natural habitat area on lowland farms in western Ireland. Biological Conservation 144, 1089-99.

Teagasc 2008 Soils and subsoils class. Wexford. Environmental Protection Agency. 
FIELD BOUNDARIES' CONTRIBUTION TO SEMI-NATURAL HABITATS ON LOWLAND FARMS

Appendix $A-\chi^{2}$ test values for differences in frequency of species-rich hedgerows between DEDs.

\begin{tabular}{lccccc}
\hline DED & Claregalway & Creggs & Cappard & Kilmalinogue & Scregg \\
\hline Claregalway & - & - & - & - & - \\
Creggs & $\mathrm{ns}$ & - & - & - & - \\
Cappard & $7.15^{\star \star}$ & $\mathrm{ns}$ & - & - & - \\
Kilmalinogue & $26.27^{\star \star}$ & $14.6 \star \star$ & $7.59 \star \star$ & - & - \\
Scregg & $5.20^{\star}$ & $\mathrm{ns}$ & $\mathrm{ns}$ & $6.60 \star$ & - \\
Ahascragh & $\mathrm{ns}$ & $\mathrm{ns}$ & $\mathrm{ns}$ & $23.95 \star \star$ & $\mathrm{ns}$ \\
\hline
\end{tabular}

$\chi^{2}$ test significance $\star P<0.05,{ }^{\star}{ }^{\star} P<0.01 . \mathrm{ns}=$ not significant.

Appendix $\mathrm{B}-\chi^{2}$ test values for differences in frequency of favourable condition hedgerows between DEDs.

\begin{tabular}{lccccc}
\hline DED & Claregalway & Creggs & Cappard & Kilmalinogue & Scregg \\
\hline Claregalway & - & - & - & - & - \\
Creggs & $\mathrm{ns}$ & - & - & - & - \\
Cappard & $4.46^{\star}$ & $\mathrm{ns}$ & - & - & - \\
Kilmalinogue & $6.05^{\star}$ & $\mathrm{ns}$ & $\mathrm{ns}$ & - & - \\
Scregg & $\mathrm{ns}$ & $\mathrm{ns}$ & $\mathrm{ns}$ & $\mathrm{ns}$ & - \\
Ahascragh & $5.57 \star$ & $\mathrm{ns}$ & $\mathrm{ns}$ & $\mathrm{ns}$ & $\mathrm{ns}$ \\
\hline
\end{tabular}

$\chi^{2}$ test significance $\star P<0.05$. ns $=$ not significant. 